\title{
An Empirical Study on the Factors Affecting the Job Satisfaction of Hotel Employees
}

\author{
- A case study of five-star hotels in Fuzhou
}

\author{
Xie Lechen, Wang Wenlan* \\ Fujian Agriculture And Forestry University
}

\begin{abstract}
To provide a basis for exploring effective strategies for hotel management based on the job satisfaction of employees, while reducing brain drain and improving hotel service levels. This paper uses five-star hotel employees in Fuzhou as a sample, select the department staff to conduct a questionnaire survey, uses stepwise multiple linear regression to analyse employee job satisfaction of the key factors of empirical research. The results show that there are significant positive correlations among age, department, working environment, salary and welfare, reward and punishment system, training opportunity, promotion mechanism and management system and employee job satisfaction.
\end{abstract}

Keywords-five-star hotel; employee satisfaction; affecting factors; empirical research

\section{INTRODUCTION}

According to Wanous [1], Heskett et al. [2], Kuang Jiaqing [3] and other scholars have shown that there is a positive correlation between employee job satisfaction and job performance, and there is a negative correlation with turnover intention; Employees provide $60 \%$ of the hotel's satisfaction. It is found that employee satisfaction is critical to hotel customer satisfaction and business performance. However, the current management of the major hotels in Fuzhou, to a certain extent, neglected the analysis of employee satisfaction, thus affecting the work of the staff enthusiasm and stability, and ultimately affect the quality of the hotel's services. Based on the above analysis, this paper analyzes the satisfaction of the hotel staff, and designs the potential factors of the satisfaction of the hotel staff on the basis of the literature review. Based on the design questionnaire, the questionnaire is used to collect the first-hand data, and finally the multi-linear regression method is used to identify the hotel staff Job satisfaction, and put forward policy recommendations.

\section{The Connotation of Employee Satisfaction}

The study of job satisfaction can be traced back to the founder of the sociology of industry, the representative of the theory of interpersonal relationship Mayo (G.E.Mayo, 1933) Hawthorne experimental study. Many domestic and foreign scholars have studied the employee satisfaction from different angles, and they have their own opinions on the connotation of job satisfaction, but there is no unified definition. However, there are a number of researchers agree that the job satisfaction and emotional connection, agreeing that job satisfaction is a work-related psychological response. Accordingly, the author's job satisfaction is defined as follows: the staff of the current role of the work held by the emotional orientation, the specific performance of the staff for the job role of satisfaction.

\section{THE MEASUREMENT OF HOTEL EMPLOYEES' JoB SATISFACTION MEASUREMENT AND ITS INFLUENCING FACTORS}

\section{A. Hotel staff job satisfaction measurement variable design}

According to the literature review of employee satisfaction research, it is found that the current scholars have different opinions on the determination of employee satisfaction measurement variables. Some scholars have measured from a number of projects, such as Weiss, Dawis, England \& Lofquist (1967) prepared Minnesota job satisfaction questionnaire, including the scale is divided into short scale and long scale two, short scale 20 Title, long scale has 120 questions [4]; Spector.paul E prepared the job satisfaction scale includes salary, promotion, supervision, additional income, performance bonus, working conditions, colleagues relations, job characteristics and communication 9 dimensions, a total of 36 indicators [5]; Some scholars use the overall job satisfaction to measure a single indicator, such as Niu Honghuan [6]. Through the analysis, it is found that there are some drawbacks of the employee job satisfaction measurement scale which includes multiple items and it is not enough to find out the key influencing factors of employee satisfaction. Therefore, this article draws on Niu Honghuan's point of view, only set the overall job satisfaction of the staff as the study of the dependent variable.

\section{B. Analysis on the Affecting Factors of Hotel Employees' Job Satisfaction}

Domestic and foreign scholars on the job satisfaction of employees also a lot of theoretical and empirical research. The main theories used in employee job satisfaction research include content theory, process theory, situational model, reinforcement theory, need hierarchy theory, two factor theory, and work characteristic theory [7]. In the empirical research, Hou Pingping through the factor analysis that the emotional intelligence of the staff will have a higher job satisfaction [8]; Niu Honghuan design of the hotel staff satisfaction with the impact of factors such as job satisfaction, organizational 
environment, scenic and hotel management, Working environment, interpersonal relationship, gender, age, education level, length of service, marriage and other 10 factors [6]; and so on.

Basing on the above analysis, this paper intends to study the relationship between age, gender, marriage, education, service, service, service, training, Promotion mechanism, coordination mechanism, management system, participation in management and other 20 factors on the Fuzhou 5 - star hotel staff satisfaction analysis.

\section{QUESTIONNAIRE DESIGN AND DATA COLLECTION}

\section{A. Survey design}

The first part is mainly the basic information of the respondents, including sex, age, marriage, education, length of service, department and other six projects; the second part is the staff job satisfaction, work pressure, work Environment and other 12 variables of the measurement scale, to take the form of Lee Kurt to design. In this paper, for the employee's job satisfaction measurement variable, 1 for "very dissatisfied", 2 for "less satisfied", 3 for "general", 4 for "satisfaction", 5 for "very satisfied"; for other Measurement of variables, 1 means "very disagree", 2 said "less agree", 3 said "general", 4 said "more agree", 5 said "very agree".

\section{B. Data collection}

After the completion of the questionnaire design, the author in the Shangri-La Hotel, Century Golden Resources Hotel, West Lake Hotel and other six five-star hotel face-to-face interviews with the questionnaire survey, the survey involved in various hotels in the Ministry of Finance, Marketing department, catering department, guest room department, entertainment department, front office department, human resources department and other eight departments of grassroots employees. A total of 150 questionnaires were sent, and some incomplete questionnaires were discarded. The effective questionnaires were 136 , and the effective recovery rate was $90.67 \%$.

According to the data collection, gender, the majority of women, accounting for $72.06 \%$ of the sample; age, $20-30$ years of age accounted for 69.12; marriage, unmarried samples accounted for $68.38 \%, 31.62 \%$ married; To high school and specialist, accounting for $38.24 \%$ and $35.29 \%$ respectively; service age, more than half of the staff did not work in the hotel for more than 2 years, the proportion of $72.06 \%$, which are with the hotel staff to unmarried women, Low academic qualifications, young staff structure, resulting in a higher turnover rate of the actual staff.

\section{DESCRIPTIVE ANALYSIS OF EMPLOYEE SATISFACTION MEASUREMENT INDEX AND ITS AFFECTING FACTORS}

\section{A. A descriptive analysis of employee satisfaction}

According to Table 1, no staff expressed dissatisfaction with the work; 30 people were less satisfied with the work, accounting for $22.06 \%$; 82 people said that the general satisfaction with the work, accounting for $60.29 \%$; 23 people expressed satisfaction with the work, accounting for $16.91 \%$; only one person expressed satisfaction with the work, accounting for 0.74 . In general, the average score of employee overall satisfaction is 2.963 , which is at the general level, indicating that the satisfaction of the hotel staff is generally at the general level and the room for improvement.

TABLE I EMPLOYEE Job SATISFACTION SURVEY

\begin{tabular}{|c|c|c|c|c|c|c|}
\hline & $\begin{array}{c}\text { very } \\
\text { dissatisfie } \\
\mathrm{d}\end{array}$ & $\begin{array}{c}\text { less } \\
\text { satisfied }\end{array}$ & generally & $\begin{array}{c}\text { less } \\
\text { satisfied }\end{array}$ & $\begin{array}{c}\text { Very } \\
\text { dissatisfied }\end{array}$ & $\begin{array}{c}\text { The average } \\
\text { score }\end{array}$ \\
\hline $\begin{array}{c}\text { Number of } \\
\text { samples / people }\end{array}$ & 0 & 30 & 82 & 23 & 1 & \multirow{2}{*}{2.963} \\
\hline proportion /\% & 0.00 & 22.06 & 60.29 & 16.91 & 0.74 & \\
\hline
\end{tabular}

B. A Descriptive Analysis of Factors Affecting Employee Satisfaction

Table 3 is the survey sample in the various indicators on the proportion of each assignment. In addition to participating in management indicators, most of the assignment focused on very dissatisfied, less satisfied and generally three assignments. Table 2 shows that employee satisfaction with all indicators is at a low level.

TABLE II A CASE Study of Employee Job Satisfaction

\begin{tabular}{|c|c|c|c|c|c|c|}
\hline & $\begin{array}{l}\text { very } \\
\text { dissatisfied/\% }\end{array}$ & less satisfied $/ \%$ & $\begin{array}{c}\text { generally } \\
/ \%\end{array}$ & $\begin{array}{c}\text { less satisfied } \\
/ \%\end{array}$ & $\begin{array}{c}\text { Very } \\
\text { dissatisfied } / \%\end{array}$ & $\begin{array}{c}\text { The average } \\
\text { score }\end{array}$ \\
\hline Nature of the work & 2.21 & 29.41 & 50.00 & 16.18 & 2.21 & 2.868 \\
\hline Working system & 10.29 & 37.50 & 41.91 & 5.15 & 5.15 & 2.574 \\
\hline Working pressure & 0.00 & 27.94 & 52.94 & 17.65 & 1.47 & 2.926 \\
\hline $\begin{array}{c}\text { working } \\
\text { environment }\end{array}$ & 10.29 & 49.26 & 35.29 & 4.41 & 0.74 & 2.360 \\
\hline $\begin{array}{c}\text { A sense of } \\
\text { accomplishment }\end{array}$ & 3.68 & 13.24 & 52.21 & 30.15 & 0.74 & 3.110 \\
\hline \begin{tabular}{c} 
sense of trust \\
\hline
\end{tabular} & 5.15 & 32.35 & 46.32 & 13.24 & 2.94 & 2.765 \\
\hline
\end{tabular}




\begin{tabular}{|c|c|c|c|c|c|c|}
\hline \multicolumn{7}{|c|}{ Table II, cont. } \\
\hline $\begin{array}{c}\text { Compensation and } \\
\text { benefits }\end{array}$ & 6.62 & 46.32 & 34.56 & 11.03 & 1.47 & 2.544 \\
\hline $\begin{array}{c}\text { Reward and } \\
\text { punishment } \\
\text { system }\end{array}$ & 0.74 & 7.35 & 40.44 & 37.50 & 13.97 & 3.566 \\
\hline $\begin{array}{c}\text { Training } \\
\text { opportunities }\end{array}$ & 0.00 & 39.71 & 44.85 & 13.97 & 1.47 & 2.772 \\
\hline $\begin{array}{c}\text { Interpersonal } \\
\text { relationships }\end{array}$ & 13.97 & 39.71 & 31.62 & 11.03 & 3.68 & 2.507 \\
\hline $\begin{array}{c}\text { Promotion } \\
\text { mechanism }\end{array}$ & 0.74 & 39.71 & 50.00 & 8.82 & 0.74 & 2.691 \\
\hline $\begin{array}{c}\text { Coordination } \\
\text { mechanism }\end{array}$ & 0.00 & 26.47 & 39.71 & 29.41 & 4.41 & 3.118 \\
\hline $\begin{array}{c}\text { Management } \\
\text { System }\end{array}$ & 1.47 & 29.41 & 52.94 & 15.44 & 0.74 & 2.846 \\
\hline $\begin{array}{c}\text { Participate in } \\
\text { management }\end{array}$ & 27.94 & 30.15 & 23.53 & 17.65 & 0.74 & 2.331 \\
\hline
\end{tabular}

\section{AN EMPIRICAL STUDY ON THE FACTORS AFFECTING EMPLOYEE SATISFACTION}

\section{A. Construction of Multiple Linear Regression Model}

After obtaining the first-hand data and passing the reliability test and the validity test, this paper uses the multiple linear regression method to find the key influencing factors of the job satisfaction of the 5-star hotel staff. Therefore, the linear regression model designed in this paper is based on the work satisfaction of 136 samples as the dependent variable, age (age), sex (Sex), marriage (Mar), education (Addu), length of service (Gl) (A), trust (Tru), salary and welfare (Sal), reward and punishment system (Awa), work system (S), work pressure (Pre), working environment (Env) (Tra), interpersonal relationship (Rel), promotion mechanism (Pro), coordination mechanism (Coo), management system (Man), participation management (Inv) and other 20 indicators as independent variables, and then establish a multiple linear regression model as follows:

$$
\begin{aligned}
& \text { JYJX }=b_{0}+b_{1} \text { Age }+b_{2} \text { Sex }+b_{3} \text { Mar }+b_{4} A d d u+b_{5} G l \\
& +b_{6} \text { Dep }+b_{7} \text { Work }+b_{8} \text { Sb }+b_{9} \operatorname{Pr} e+b_{10} E n v+b_{11} A c h \\
& +b_{12} \text { Tru }+b_{13} \text { Sal }+b_{14} \text { Awa }+b_{15} \text { Tra }+b_{16} \text { Rel }+b_{17} \text { Pro } \\
& +b_{18} \text { Coo }+b_{19} \text { Man }+b_{20} \text { Inv }+\varepsilon
\end{aligned}
$$

\section{B. Analysis of model test results}

After constructing the conceptual model of multiple linear regression equation, this paper uses the sample data collected by the survey and uses the stepwise regression analysis function of SPSS17.0 statistical analysis software to carry out the model test. The test results are shown in Table 3, Table 4 and Table5.

It can be seen from Table 4 that the fitting degree of the regression model $\mathrm{R}=0.687$ and the goodness of fit $\mathrm{R} 2=0.472$, which shows that the model has better fitting toughness. At the same time, it can be seen from Table 5 that the goodness of the model is more significant, Because of its $F$ value of 5.955, p value of 0 , indicating that at least some variables have a strong explanatory power, such as age, length of service, work, work environment, pay and benefits, training opportunities, promotion mechanism and other nine factors.

TABLE III MODEL SUMMARY ${ }^{\mathrm{I}}$

\begin{tabular}{|c|c|c|c|c|c|}
\hline Model & $\mathrm{R}$ & R square & $\begin{array}{c}\text { Adjustment R } \\
\text { square }\end{array}$ & $\begin{array}{c}\text { standard Estimated } \\
\text { error }\end{array}$ & Durbin-Watson \\
\hline 8 & $.687 \mathrm{~h}$ & .472 & .439 & .486 & 1.672 \\
\hline
\end{tabular}

h. Predictive variables: (constant), Age,Sex, Mar,

i.Dependent variable: Job Satisfaction Addu、 Gl、Dep、Work、Sb、Pre、Env、Ach、Tru、Sal、 Awa、Tra、Rel、Pro、Coo、Man、Inv. 
TABLE IV REGRESSION ANALYSIS OF VARIANCE (ANOVA $)$

\begin{tabular}{|c|l|c|c|c|c|c|}
\hline \multicolumn{2}{|c|}{ Model } & Sum of square & df & Average square & F & Sig. \\
\hline \multirow{2}{*}{8} & Regression & 26.823 & 8 & 3.353 & 14.197 & $.000^{\mathrm{h}}$ \\
\cline { 2 - 7 } & Residual & 29.994 & 127 & .236 & & \\
\cline { 2 - 7 } & totle & 56.816 & 135 & & & \\
\hline
\end{tabular}

From Table 5, we can see that the $t$ values of Pro, Env, Man, Dep, Age, Sal, Tra, Awa and other factors are 4.100, 3.151, $1.908,2.960,2.640,3.000,2.515,2.308$, respectively The probability is $0.000,0.002,0.059,0.004,0.009,0.003,0.013$, 0.023 , both less than 0.10 , indicating that the coefficients of

these variables are significantly different from 0 , which can be retained in the regression equation. And sex, Mar, Addu, Gl, Work, Sb, Pre, Ach, Tru, Rel, Coo, Inv and other 12 factors were excluded from the regression equation.

TABLE V REGRESSION COEFFICIENT AND SIGNIFICANCE TEST TABLE (COEFFICIENTS ${ }^{\mathrm{A}}$ )

\begin{tabular}{|c|c|c|c|c|c|c|}
\hline \multirow{2}{*}{\multicolumn{2}{|c|}{ Model }} & \multicolumn{2}{|c|}{ Non - standardized coefficient } & \multirow{2}{*}{$\begin{array}{c}\begin{array}{c}\text { Standard } \\
\text { coefficient }\end{array} \\
\text { trial version } \\
\end{array}$} & \multirow[t]{2}{*}{$\mathrm{t}$} & \multirow[t]{2}{*}{ Sig. } \\
\hline & & B & trial version & & & \\
\hline \multirow{9}{*}{8} & Constant & .175 & .314 & & .556 & .579 \\
\hline & Pro & .299 & .073 & .309 & 4.100 & .000 \\
\hline & Env & .198 & .063 & .230 & 3.151 & .002 \\
\hline & Man & .130 & .068 & .144 & 1.908 & .059 \\
\hline & Dep & .097 & .033 & .200 & 2.960 & .004 \\
\hline & Age & .130 & .049 & .188 & 2.640 & .009 \\
\hline & Sal & .165 & .055 & .212 & 3.000 & .003 \\
\hline & Awa & .120 & .052 & .157 & 2.308 & .023 \\
\hline & Tra & .159 & .063 & .181 & 2.515 & .013 \\
\hline
\end{tabular}

a. Dependent variable: Job Satisfaction

\section{TEST CONCLUSIONS AND POLICY RECOMMENDATIONS}

First, the coefficient of promotion mechanism is $0.299, \mathrm{P}$ value is 0 , indicating that the hotel staff satisfaction has a significant positive effect. The results show that hotel managers should establish a sound promotion mechanism for employees to provide equal promotion opportunities to enhance employee satisfaction.

Second, the working environment coefficient is $0.198, \mathrm{P}$ value is 0.002 , indicating that the hotel staff satisfaction has a significant positive effect. The results show that the hotel's environment not only affects customer satisfaction, but also affect the staff's job satisfaction. Therefore, the hotel can understand the staff to improve the work environment, enhance the enthusiasm of the staff work.

Thirdly, the coefficient of the management system is 0.130 and the $\mathrm{P}$ value is 0.059 , which is significant under the condition of $90 \%$ confidence level, which shows that it has a significant effect on the improvement of hotel staff satisfaction. The results show that the more standardized hotel management, the higher the job satisfaction of employees. Therefore, the hotel manager should establish or improve the hotel's internal management system, to avoid the emergence of unfairness in order to enhance the staff's job satisfaction.
Fourth, the sector coefficient is $0.097, \mathrm{P}$ value of 0.004 , indicating that different departments of the job satisfaction is different. Among them, the marketing staff of the lowest job satisfaction, the average score of only 2.333 ; front office staff work the highest satisfaction, score score of 3.250 ; entertainment and human resources staff average job satisfaction score of 3.000; The Ministry of Finance, the Ministry of food, the Ministry of the staff of the staff have shown a less satisfied with the work. Therefore, the hotel manager in the consolidation of the front office, entertainment and human resources staff at the same time the satisfaction of the work, should pay attention to the marketing department, finance department, catering department and the staff of the Department of the satisfaction of the staff to enhance the work.

Fifth, the age coefficient of 0.130 , P value of 0.009 , indicating that the hotel staff satisfaction with a significant positive correlation. The results show that older employees are more satisfied with their work. Therefore, the hotel can enhance the spirit of the young employees to encourage, providing a good on-the-job training and career development planning, it can improve their job satisfaction.

Sixth, the coefficient of pay and benefits 0.165 , P value of 0.003 , indicating that the hotel staff satisfaction has a significant positive correlation. This result shows that the higher the level of employee benefits and benefits, the higher 
the job satisfaction. Therefore, the hotel should be based on the performance of employees, as far as possible to improve staff compensation, benefits and other material treatment, paying attention to material incentives.

Seventh, the reward and punishment system coefficient of $0.120, \mathrm{P}$ value of 0.023 , indicating that it has a significant positive correlation with the hotel staff satisfaction, that is, employees that their departments reward and punishment system more clearly, the more reasonable, the job satisfaction high. Therefore, the hotel manager should solve the staff's expectations and distribution of the two links to enhance their job satisfaction, so that they are from the heart to work enthusiasm.

Eighth, the training opportunity coefficient of $0.159, \mathrm{P}$ value of 0.013 , indicating that it has a significant positive correlation with the hotel staff satisfaction, that is, employees that the hotel on its in-service training, the higher the degree of attention, the higher the job satisfaction. Therefore, the hotel manager should be multi-angle, multi-level, and multi-channel to enrich professional training content.

\section{CONCLUSION}

According to the literature review results, this paper designs 20 potential influencing factors of job satisfaction of 20 hotel employees. Then, we designed the questionnaire and collected the first-hand data. We used the collected data and used multiple linear regression analysis to identify the key influencing factors of employee's job satisfaction. The results showed that: age, department, working environment, salary and welfare, reward and punishment system Opportunities, promotion mechanism, management system and other eight factors and employee job satisfaction there is a significant positive correlation. The results of this study provide theoretical guidance and practical basis for improving the employee satisfaction policy in Fuzhou 5-star hotel managers.

\section{ACKNOWLEDGMENT}

Xie Lechen, Fujian Agriculture And Forestry University College of Economics doctoral candidate, mainly engaged in agricultural and forestry economic theory research, E-mail: 1e5315@sina.com.

Wang Wenlan, Fujian Agriculture And Forestry University College of Economics professor, doctoral tutor, mainly engaged in agroforestry theory research, E-mail: wzg916@163.com, as corresponding author.

\section{REFERENCES}

[1] Wanous J P. A Causal-corelational Analysis of the job-satisfation and Performance Relationship [J]. Journal of Applied Psychology, 1974, (53): 1-11.

[2] Heskett J L, Jones T O, Loveman GW, et al. Putting the sercive2p rofit chain to work [J]. Halvard Business Review, 1994, (3-4): 164-174.

[3] Kuang Jiaqing. Hotel staff job satisfaction conceptual model construction and evaluation [J]. Finance and Economics Research, 2014, (S1): 231-234. (In Chinese)

[4] Weiss, D. J., Davis, R V, England, G. W., \& Lofquist, L. H. Manual for the Minnesota Satisfaction Questionnaire [C]. Minneapolis, MN: The University of Minnesota Press, 1967.

[5] Spector, P E.. Job satisfaction: Application, assessment, causes, and consequences [C]. Thousand Oaks, CA. Sage, 1997.

[6] Niu Honghuan. Study on influencing factors of job satisfaction of scenic hotel staff - Taking Tianmu Lake scenic spot in Jiangsu as an example [D]. Shanghai: East China Normal University, 2008. (In Chinese)

[7] Sun Jianfa. Employee job satisfaction factors [D]. Shandong Jinan: Shandong University, 2006. (In Chinese)

[8] Hou Pingping. Hotel front-line staff emotional intelligence on the impact of job satisfaction mechanism [D]. Jinan University, 2016. (In Chinese) 